TITLE:

\title{
Pore-pressure generation and fluidization in a loess landslide triggered by the 1920 Haiyuan earthquake, China: A case study
}

\section{$\operatorname{AUTHOR}(\mathrm{S})$ :}

Wang, Gonghui; Zhang, Dexuan; Furuya, Gen; Yang, Jun

\section{CITATION:}

Wang, Gonghui ... [et al]. Pore-pressure generation and fluidization in a loess landslide triggered by the 1920 Haiyuan earthquake, China: A case study. Engineering Geology 2014, 174: 36-45

ISSUE DATE:

2014-05-23

URL:

http://hdl.handle.net/2433/187111

\section{RIGHT:}

(C) 2014 Elsevier B.V.; This is not the published version. Please cite only the published version.; この論文は出版社版でありません。引用の際に は出版社版をご確認ご利用ください。 


\section{Submitted to: Engineering Geology}

2

3

4

5

6

7

8 Gonghui Wang, D. Sci (Corresponding author)

9 Research Center on Landslides

10 Disaster Prevention Research Institute

11 Kyoto University

12

Gokasho, Uji, 611-0011

13 Japan

14 Tel: (+81)774-384114; Fax:(+81)774-384300

15

16

17

18 School of Naval Architecture, Ocean and Civil Engineering

19 Shanghai Jiao Tong University

20 Huashan Road, 1954

21 Shanghai, 200030

22 P.R. China

23

E-mail: dxzhang@sjtu.edu.cn

24

Jun Yang, D. Eng,

31 Department of Civil Engineering

32 The University of Hong Kong

33 Pokfulam, Hong Kong

34 P.R. China earthquake, China: A case study

Gonghui Wang ${ }^{1}$, Dexuan Zhang ${ }^{2}$, Gen Furuya ${ }^{3}$, Jun Yang ${ }^{4}$ 
35 Abstract: During the 1920 Haiyuan earthquake, numerous catastrophic landslides were triggered in the loess 36 area in Northwest China. We investigated in detail a large example of these landslides, referred to as Dangjiacha 37 landslide in this paper. This landslide originated from a slope of about 20 degrees, and the displaced soil mass 38 traveled about $3200 \mathrm{~m}$, damming a valley. We performed a field survey and found that standing water existed in 39 the landslide area and the loess had high porosity. We infer that it was the liquefaction of the water-saturated 40 loess layer rather than the suspension of silt in the pore-air in the loess that caused the great mobility of this 41 landslide. To test this inference, we performed undrained triaxial compression and ring shear tests on loess samples to examine the shear behavior of loess saturated by either air or water. The test results showed that the water-saturated loess soil was highly susceptible to flow liquefaction failure. Fast shear tests on naturally 44 air-dried loess samples revealed that the generated pore-air pressure was small under the "undrained condition" 45 and no significant reduction in the shear resistance was observed, implying that air entrapped in the loess was unlikely to be the main contributor to the high mobility of this large-scale landslide.

Keywords: loess landslide, Haiyuan earthquake, liquefaction, excess pore-water pressure, air-pressure, high 49 mobility 


\section{Introduction}

Due to their disastrous consequences, rapid landslides with long runout distance pose a great challenge to both geologists and geotechnical researchers. Much research has been performed in attempts to better understand the mechanism of this kind of landslide. Different assumptions were proposed for the mechanisms of these rapid landslides, and they can be categorized into the following five groups (Lucchitta, 1979): (1) flow involving debris and air (Kent, 1966; Varnes, 1978); (2) flow involving debris alone (Howard, 1973; Hsü, 1975; ); (3) flow involving debris and water (Plafker and Erickson, 1978); (4) debris sliding on a cushion of air (Shreve, 1968); and (5) debris sliding on a cushion of steam (Pautre et al., 1974; Habib, 1975). Although the assumptions (1), (3), (4), and (5) are somewhat different from each other, they all suggest that the involvement of entrained fluid (air or water) plays a key role in the rapid, long-distance movement.

During the 1920 Haiyuan earthquake $(M=8.5)$, a great number of catastrophic landslides was triggered in the loess area of the northwestern part of China (Fig. 1) that killed more than 100,000 people (Close and McCormick, 1922) and formed many landslide-dams (Zhu, 1989a, b; Derbyshire, 1991; Derbyshire et al, 2000; Dijkstra et al, 1994). Up to present, many research studies have been performed and different hypotheses have been proposed to improve understanding of catastrophic landslides. Generally, it has been widely accepted that catastrophic earthquake-induced landslides were mainly caused by soil liquefaction (Seed, 1966). For example, Ishihara et al. (1990) investigated the large-scale landslides triggered by an earthquake in the suburb of Dushanbe, the capital of the Tajikistan Republic (January 23, 1989, M = 5.5), and concluded that liquefaction occurred in the landslides masses due to the high collapsibility of the loess soil that may have been saturated by irrigation water. However, for the loess landsides triggered by the 1920 Haiyuan earthquake, different views appear to exist. Varnes (1978) regarded these landslides as dry loess flows in his landslide classification. Ter-Stepanian (1998) thought that these landslides were dry loess flows due to the generation of high pore-air pressure. Keefer (1984) studied the landslides triggered by 40 major earthquakes that occurred throughout the world and classified loess landslides as a kind of rapid soil flow.

The mechanisms above proposed for the loess landslides appear to be reasonable, because the loess plateau is generally in a semi-arid environment and the loess has large porosity. In addition, the loess soil is composed mainly of fine grains and its liquefaction potential during earthquakes is usually considered to be low (Yoshimi, 1991). Nevertheless, recent studies revealed that soils composed almost entirely of silt are liquefiable (Fletcher $e t$ al., 2002; Wang and Sassa, 2002; Wang et al., 2007; Zhang et al., 2013). Zhang and his colleagues (Zhang et al., 1995; Zhang and Sassa, 1996; Zhang and Wang, 2007) performed detailed geomorphologic studies of the loess landslides triggered by the 1920 Haiyuan earthquake and found that slopes in the landslide source areas were gentle and most landslides occurred on concave slopes. Hence, they concluded that these highly mobile loess landslides mainly resulted from liquefaction during the earthquake.

To further clarify the mechanisms of these loess landslides, we investigated a large-scale landslide that occurred in Dangjiacha area, Xiji county, Ningxia Province, China (hereinafter termed Dangjiacha landslide). Evidence for abundant groundwater in the landslide source area was found during our field investigation. We then conducted a series of laboratory tests to examine loess samples taken from the landslide source area. This paper presents the field survey and laboratory findings, and then discusses the possible mechanisms contributing to the rapid, long-distance runout of loess landslides. 
89

90

91

92

93

94

95

\section{Dangjiacha landslide}

Located approximately $25 \mathrm{~km}$ southwest of Xiji city, Dangjiacha landslide was the most catastrophic one triggered by the 1920 Haiyuan earthquake. Figs. 2 and 3 present an airphoto (taken in 1966) and the topography of the landslide area, respectively. The landslide was composed of two big blocks (left and right, referring to viewing the landslide area in the downhill direction), both originating from the same side of a mountain ridge. We surveyed the landslide during 1994, 2002, 2003 and 2005. We used a total-station surveying instrument to create a transverse cross section along I-I' and longitudinal sections along lines II-II' and D-E-F-G (Figs. 2, 4). The left block of the landslide originated from a slope of about 20 degrees and nearly all of it evacuated the source area, while the right block stopped after moving a relatively shorter distance. The left block has a maximum width of about $520 \mathrm{~m}$ and length of $2000 \mathrm{~m}$, while the right block has a maximum width of $400 \mathrm{~m}$ and length of $1500 \mathrm{~m}$. The locations of the sliding surfaces of these two blocks were inferred from field observations and present topography, and by assuming that the ridges that form the block boundaries (Fig. 2) had not been greatly disturbed. As shown in Fig. 4, the maximum thicknesses were inferred to be approximately $50 \mathrm{~m}$ and 40 $\mathrm{m}$ for the left and right blocks, respectively. The total volume of the landslide was estimated to be approximately $2.1 \times 10^{7} \mathrm{~m}^{3}$, assuming an average deposit thickness of $20 \mathrm{~m}$. Our observations suggest that the right block moved about $230 \mathrm{~m}$ (assuming that the materials at point P in Fig. 4b originated from the uppermost part of the scar) and did not experience much deformation during movement. In contrast, the left block was nearly entirely displaced out of the source area, moved northwards for a distance of about $2000 \mathrm{~m}$ before turning westwards for an additional $1100 \mathrm{~m}$, and its deposit dammed the valley. A barrier lake formed that is about $5 \mathrm{~km}$ long and $380 \mathrm{~m}$ wide; it is the largest of the recorded impounded lakes formed by this earthquake (Derbyshire et al., 2000).

We observed standing water (Fig. 5) and shallow groundwater (Points W1 and W2 in Fig. 2) in the landslide source areas, even 80 years after the 1920 earthquake. Point W2 references a well that supplies water for several families, with a water table $22 \mathrm{~m}$ (measured on March 26, 2003) below the present ground surface. We were told that the groundwater table in W2 was usually higher during summer. Well W1 is very shallow. To examine the aquifer location, we dug a pit near W1 on March 20, 2005, and found groundwater at a depth of about $2 \mathrm{~m}$ (Fig. $5 c)$.

Although the groundwater condition may be different from that of 80 years ago, it is reasonable to believe that the displaced landslide mass was rich in groundwater before the earthquake, because: (1) for this area, the annual potential evapotranspiration is about $1500 \mathrm{~mm}$, while the annual precipitation is less than $400 \mathrm{~mm}$ (Derbyshire et al., 2000; Chen et al., 2003). This unbalance has led to a severe water deficit resulting in the area being drier at present than during 1920; (2) the groundwater table might have dropped due to the removal of the landslide mass; and (3) long-term groundwater withdrawal by area residents using the wells in the landslide source area might have further lowered the groundwater table.

We measured the in-situ densities of the loess soils at multiple heights on the main scarp (along line D-E in Fig. 2), and then calculated the void ratios of these soil layers after measuring the specific gravity of the loess (see Fig. 6). The soil layers at different elevations had different void ratios, ranging from 0.79 to 1.31 . Generally, soils at lower elevation had lower void ratio, and the minimum void ratio (highest density) was measured for location S1. To study the initiation and movement mechanisms of the landslide in the laboratory, we took intact 
samples (two blocks, each sized $50 \mathrm{~cm} \times 40 \mathrm{~cm} \times 40 \mathrm{~cm}$ ) at location $\mathrm{S} 1$ and disturbed samples $($ about $80 \mathrm{~kg})$ at location S2 from the main scarps (see Figs. 2 and 4). These samples were taken from two pits that were dug approximately $1 \mathrm{~m}$ deep. We hypothesized that liquefaction failure of the water-saturated loess was the main reason for this long-runout landslide, and if the soil at location S1 was liquefiable, then all soil layers would be liquefiable as they had higher void ratios than at $\mathrm{S} 1$.

The liquefaction potential of the loess samples was examined by means of undrained triaxial compression tests and undrained ring shear tests. Undrained triaxial compression tests were performed on undisturbed samples to examine the possible occurrence of flow liquefaction, and ring shear tests were performed on disturbed loess samples to examine the undrained shear strength at the "real steady state" (Poulos, 1981; Wang and Sassa, 2002). Compared with the ring shear test, the strain level in the triaxial test is limited and the real steady state as defined by Poulos (1981) may not be reached by the end of a triaxial test. In addition, we also performed fast undrained ring shear tests on naturally air-dried loess samples with entrapped pore air to examine the possible role of air in the rapid movement of loess landslides.

\section{Undrained shear test results 3.1 Characteristics of loess sample}

Following the standards of JGS (Japanese Geotechnical Society), the basic properties of the loess were measured, and some characteristics are listed in Table 1. Note that the minimum and maximum densities in Table 1 were obtained following ASTM procedures for sands, although the loess sample is a silty soil. The grain size distribution (shown in Fig. 7) was obtained following ASTM standard D422-63 (2007). As shown, the sample consists of about $93 \%$ silt, $2 \%$ sand, and $5 \%$ clay.

The microstructures of the undisturbed and remolded loess samples were observed using the SEM technique (Fig. 8 and Fig. 9). Both samples consist of a loosely packed silt skeleton with finer particles coating larger particles forming aggregates. However, the aggregates in the undisturbed loess form bigger clusters (like pupa), while those in the remolded loess form a relatively homogenous structure.

\subsection{Undrained triaxial compression tests}

A series of consolidated-undrained triaxial compression tests was performed on undisturbed samples. The specimens had a height of $10 \mathrm{~cm}$ and a diameter of $5 \mathrm{~cm}$. All specimens were saturated with de-aired water assisted by $\mathrm{CO}_{2}$ saturation. Water saturation was ensured by obtaining a B value (Skempton, 1954) of at least 0.95. After saturation, the specimens were consolidated under a given cell pressure, and then compressed under undrained conditions following the strain-controlled method. Axial strain was increased at a rate of $0.01 \%$ per minute. The specimens were consolidated and tested at cell pressures of 100, 200, 300, and $400 \mathrm{kPa}$. Note that these cell pressures were used for observing the collapse behavior at different initial consolidation stresses, as done in many studies (Sladen et al., 1985; Ishihara, 1993). The triaxial compression at each cell pressure was terminated when the axial strain reached $30 \%$. Fig. 10 presents the test results in the form of pore-water pressure against axial strain (Fig. 10a) and effective stress path (Fig. 10b). It can be seen that high pore pressure was generated, resulting in a remarkable decrease in effective stress. The final pore pressures in the tests were as great as $65 \%$ of the initial cell pressures. The locus of peak points in the effective stress paths can be well fitted by a straight line passing through the origin. This line is widely known as the flow liquefaction line (FLL) (Vaid 
and Chern, 1983, 1985; Lade, 1993; Ishihara, 1993; Kramer, 1996; Yang, 2002), which indicates the initiation of flow deformation. The stress ratio, defined as the ratio of $\mathrm{q}\left(=\left(\sigma_{1^{-}}-\sigma_{3}\right) / 2\right)$ to $\mathrm{p}^{\prime}\left(=\left(\sigma_{1}+\sigma_{3}\right) / 2\right)$, is approximately 0.4, which corresponds to a mobilized friction angle of about 21.8 degrees. From these test results (Fig. 10b), we can conclude that the loess is susceptible to flow liquefaction failure.

\subsection{Undrained ring shear apparatus}

The ring shear apparatus allows the residual shear strength of soil to be obtained at large shear displacements and, therefore, has been widely used in landslide studies (e.g., Bishop et al., 1971; Bromhead, 1979; Gibo, 1994; Tika and Hutchinson, 1999; Liao et al., 2011). A series of undrained ring shear apparatus (DPRI-4, 5, 6, and 7) developed by Kyoto University (Sassa et al., 2004) has been used to study landslides triggered by rainfall, earthquakes, impoundment of reservoir water, irrigation, etc. (e.g., Wang et al., 2002; 2003; Okada et al, 2004; Zhang and Wang, 2007; Zhang et al., 2013; Miao et al., 2014). In this research, DPRI-5 and DPRI-7 were used. DPRI-5 has a shear box with $120 \mathrm{~mm}$ inner diameter, $180 \mathrm{~mm}$ outer diameter, and $115 \mathrm{~mm}$ height, an available maximum shear velocity of $10 \mathrm{~cm} / \mathrm{s}$ and an available maximum normal stress of 2,000 kPa. DPRI-7 has a larger shear box that is transparent $(270 \mathrm{~mm}$ inner diameter, $350 \mathrm{~mm}$ outer diameter, and $115 \mathrm{~mm}$ height) and can produce a higher shear velocity (as much as $300 \mathrm{~cm} / \mathrm{s}$ ) under an available maximum normal stress of $500 \mathrm{kPa}$. Tests can be conducted with both ring shear apparatuses by controlling shear torque or shear speed under undrained conditions with the ability to measure pore-water pressure. In this study, DPRI-5 was used for all tests on water-saturated samples, while DPRI-7 was used for the fast shear tests on air-dried samples. Additional details of the design and construction of these apparatus, as well as the operation method, can be found in Sassa et al. $(2003,2004)$.

\subsubsection{Test results for water-saturated loess}

Because all of the samples were consolidated under the same initial normal stress, the dry-deposition method (Ishihara, 1993) was used to prepare the samples to different initial densities. The oven-dried soil was poured into the shear box freely in several layers, and each layer was tamped. Different initial densities were obtained by tamping differently.

The samples were saturated with de-aired water assisted by carbon dioxide. For all tests, the degree of saturation was checked by measuring the $B_{D}$ parameter, which was proposed by Sassa (1985) for use in the direct-shear state. $B_{D}$ is defined as the ratio between the increment of generated excess pore pressure $(\Delta u)$ and normal stress $(\Delta \sigma)$ in the undrained condition, and formulated as $B_{D}=\Delta u / \Delta \sigma$. If $B_{D} \geq 0.95$, this indicates that the sample is approximately fully saturated. In this study, all samples were saturated with $B_{D} \geq 0.95$. After saturation, samples were consolidated at a given normal stress. Because the purpose of this study was to examine the liquefaction characteristics of loess, a consolidation normal stress of $200 \mathrm{kPa}$ was used for all tests because at this value our ring shear apparatus can performs best; also, we have accumulated many results from undrained shear tests performed on different types of soils under this normal stress. After consolidation, samples were brought to failure by increasing the shear stress at a loading rate of $0.098 \mathrm{kPa} / \mathrm{s}$ under undrained conditions. All samples were sheared until the shear resistance became constant. 
The results of a test on a water-saturated loess sample with initial void ratio of 1.06 are shown in Fig. 11, where normal stress, pore-water pressure, and shear resistance are plotted against shear displacement (Fig. 11a). Fig. 11b shows the effective-stress path. It is noted that pore pressures are measured by pore pressure transducers connected to a gutter $(4 \times 4 \mathrm{~mm})$ located along the entire circumference of the inner wall of the outer ring in the upper cylinder pair of the specimen chamber, $2 \mathrm{~mm}$ above the shear surface. More details on the pore-water pressure monitoring system can be found in Sassa et al. (2003). From Fig. 11a, it can be seen that the pore-water pressure increased with increasing shear displacement before reaching a great value (about $85 \%$ of the applied normal stress), while shear resistance decreased to a small, nearly constant value (about $10 \mathrm{kPa}$ ) after about 1000 $\mathrm{cm}$ of shear displacement; hence, steady-state resistance was reached.

Cyclic loading tests were also conducted on a water-saturated loess sample. After saturation, the sample was consolidated under a normal stress of $200 \mathrm{kPa}$ while a shear stress of $80 \mathrm{kPa}$ was applied. After consolidation, a cyclic shear loading was applied under undrained conditions with an amplitude of $60 \mathrm{kPa}$ and frequency of 0.25 $\mathrm{Hz}$, while the normal stress was kept constant. Fig. 12 presents the test results in the form of time-series data of normal stress, shear resistance and pore-water pressure (Fig. 12a), and in the form of the effective stress path

(Fig. 12b). Shear failure was triggered during the first cycle and pore-water pressure increased continuously thereafter, while shear resistance decreased until reaching a small, constant value (about $7.6 \mathrm{kPa}$ ). It is noted that the measured shear resistance before the occurrence of shear failure represented the applied shear loading, but after failure shear loading greater than the shear resistance of soil could not be applied (Wang et al., 2007). Hence, the intended amplitude of the cyclic loading is not apparent in Fig.11, although the frequency of the applied cyclic loading is. From Figs. 11 and 12, it can be concluded that the water-saturated loess samples are highly liquefiable under undrained monotonic or cyclic shearing.

\subsubsection{Test results for loess with entrapped air}

Because the landslide area is located in an arid region and the loess has high porosity, one may argue that the low permeability of the loess prevents air from readily escaping so liquefaction can be triggered in dry loess

230 (Ter-Stepanian, 1998). However, this hypothesis has never been examined by laboratory tests. Here, to evaluate 231 the possible effect of entrapped air on the high mobility of displaced loess, a series of fast shear tests was conducted on a loess sample at its natural water content (measured as $8.5 \%$ ). The loess (some of which was in undisturbed blocks) was first placed into the shear box without tamping such that the specimen was in a very

234 loose state with high porosity. After the sample was normally consolidated under a normal stress of $100 \mathrm{kPa}$, the 235 shear box was switched to the undrained condition and the sample was sheared by increasing the shear speed quickly (up to $2 \mathrm{~m} / \mathrm{s}$ within 4 seconds). The results are shown in Fig. 13. It can be seen that air pressure increased relatively quickly during the initial 4 seconds, and then tended to reach a constant value with further shearing (Fig. 13a). During shearing, the specimen showed significant height reduction due to collapse of the soil structure and the compression of pore air. Fig. 13c presents photos transferred from video records. Before shearing, the specimen was rich in void space with a void ratio of 1.42. During shearing, shear was localized in the shear zone and some big void spaces in the soil above the shear zone (upper layer) still remained even after the shear resistance reached steady state at a shear velocity of $2 \mathrm{~m} / \mathrm{s}$. The generated air pressure was about $25 \%$ of the normal stress, which could not lead to a significant loss of shear resistance. The mobilized minimum shear 
strength $\left(\tau_{r}\right)$ was about $55 \mathrm{kPa}$, which gave a mobilized friction angle $\left(\arctan \left(\tau_{r} / \sigma_{n}\right)\right)$ of 28 degrees. However, the slope angle is about 20 degrees in the source area and is less than 2 degrees in the runout area (e.g., from Point D to E in Fig. 4). Therefore, this mobilized friction angle would not lead to the long runout movement.

\section{Discussion}

\subsection{Liquefaction potential of loess}

In the analysis of liquefaction potential of fine-grained soils, the Chinese criteria (Wang, 1979) have been widely used. Based on site observations, Wang (1979) concluded that a clayey soil is susceptible to liquefaction if it consists of less than $15-20 \%$ of grains finer than $0.005 \mathrm{~mm}$ and the water content $\left(W_{c}\right)$ to liquid limit $\left(W_{L}\right)$ ratio is greater than 0.9. Based on the work of Wang (1979), Seed and Idriss (1982) suggested that a soil is susceptible to liquefaction if the following conditions are met: (1) the fraction of grains finer than $0.005 \mathrm{~mm} \leq$ $15 \%$, (2) liquid limit $\left(W_{L}\right) \leq 35 \%$, and (3) natural water content $\left(W_{c}\right) \geq 0.9 \times W_{L}$. A recent study by Bray and Sancio (2006) of fine-grained soils suggested that loose soils with plasticity index (PI) less than 12 and $W_{c} / W_{L}>$ 0.85 are susceptible to liquefaction. Fig. 7 shows that grains finer than $0.005 \mathrm{~mm}$ comprise about $18 \%$ of the loess taken from the landslide site. The liquid limit is about 29.5\% (see Table 1) and the calculated water content of the fully saturated specimen at the densest state is $32.8 \%$; hence, $W_{c} / W_{L} \geq 1.1$. The liquidity index is 1.28 and the plasticity index is about 11.7. These index values suggest that the loess satisfies the conditions required for liquefaction that were identified during previous research.

Through a number of dynamic triaxial tests, dynamic torsion shear tests and in-situ explosion tests on saturated loess from Lanzhou, Wang et al. (2004) examined the influence of water content on loess liquefaction, concluding that if the water content of loess is above the plastic limit, full or partial liquefaction can be triggered. They also examined the relationship between coseismic ground motion and initiation of loess liquefaction and concluded that the minimum acceleration of ground motion required to trigger loess liquefaction is 100 gal or VII degree on the seismic intensity scale of China. Zhang and Wang (1995) analyzed the geological disasters in loess areas during the 1920 Haiyuan earthquake and found that the seismic intensity of the Xiji area was X degree. Therefore, it is reasonable to infer that shear failure was triggered within the loess in the source area of Dangjiacha landslide during the earthquake.

As reported by Yang (2002), the slope of the flow liquefaction line varies with both the materials and the soil state. Wen and Yan (2014) examined the influence of structure on shear characteristics of unsaturated loess and found that peak shear strength and strength parameters (cohesion and friction angle) of the loess were significantly reduced once its structure was destroyed. Considering that some loess in the lower part might have been disturbed before the earthquake by human activities, we performed three undrained triaxial compression tests on remolded loess samples to examine the possible variation of the flow liquefaction line with the soil state. The remolded samples in these tests were prepared at the same density as that of the undisturbed samples, and testing procedures were unchanged from those used during the undisturbed tests. Fig. 14 presents the test results. As can be seen, similar to results from tests on undisturbed samples, pore water pressure continuously increased with increasing axial strain, and all tests showed flow liquefaction behavior. However, the slope of the flow

280 liquefaction line is approximately 18.4 degrees, gentler than that for the undisturbed samples shown in Fig. 11b.

281 Therefore, we can conclude that the remolded loess is more prone to flow liquefaction than undisturbed loess 
when at the same density. This change in the slope of the FLL may result from the variation in the microstructure of the samples. As seen in Figs. 8 and 9, the aggregates in the undisturbed sample are larger, probably due to the presence of cementing bonds that may be destroyed during the remolding process.

If the stress path crosses the FLL during undrained shear, flow liquefaction will be initiated regardless of whether the loading is cyclic or monotonic (Void and Chern, 1983). Because the test results presented in Fig. 10 were obtained from the densest undisturbed loess sample, it is reasonable to infer that once the stress condition in the loess layer reaches the FLL due to the introduction of seismic loading, flow liquefaction will be triggered and the shear resistance will rapidly drop to the steady-state strength.

\subsection{The steady state of loess and implications for post-failure behavior}

Based on the concept of critical void ratio defined by Casagrande (1936) and on the results obtained from undrained monotonic loading tests on saturated sand, Castro $(1969,1975)$ introduced the concept of the steady-state line. Thereafter, the steady state approach for the analysis of liquefaction susceptibility has been used in practice. The most important assumption in this analysis is that the sand has a unique steady-state line in void ratio-effective stress space; this line can be determined from the results of undrained tests on loose specimens of sand, and only those sands with their initial normal stress and void ratio located above the steady state line can experience liquefaction flow failure (Castro 1969; Castro \& Poulos 1977; Poulos 1981; Kramer 1996; Yang 2002). We performed a series of monotonic shear tests on water-saturated loess specimens at different initial void ratios. Probably due to the small value of the applied initial normal stress (200 $\mathrm{kPa})$ and the specimen preparation method, the void ratios of tested specimens ranged from 0.9 to 1.1 , showing no significant difference. Each specimen was sheared to steady state. The steady-state points for all the tests are shown on the $\boldsymbol{e}$ versus $\log \left(\tau_{s}\right)$ plot (Fig. 15). Based on these data, a steady-state line was obtained by regression. Using the measured in-situ unit weight $\left(\gamma_{d}\right)$ of $15.0 \mathrm{kN} / \mathrm{m}^{3}$ (the largest value, which corresponds to a void ratio of 0.79 ) for the loess layer in the source area, a possible maximum thickness $(H)$ of about $50 \mathrm{~m}$ (from the cross section along I-I' shown in Fig. 4a), and the slope angle $(\theta)$ of 20 degrees, we estimate that the shear stress acting on the potential sliding surface ( $\tau=H \gamma_{d} \sin \theta \cos \theta$ ) before the sliding was about $180 \mathrm{kPa}$. This initial shear stress and the in-situ void ratio will plot above the steady-state line shown on Fig. 15. Hence, once shear failure occurred during the earthquake, the shear resistance of the water saturated loess layer near the sliding surface would drop to a very small value due to liquefaction, and then the great difference between the driving shear stress and the lowered shear resistance would result in the accelerating movement of displaced landslide materials.

\subsection{Role of air in the movement}

In the analysis of landside mobility, the parameter of travel angle $\left(\phi_{a}\right)$ has been widely used (Scheidegger, 1973; Cruden and Varnes, 1996; Legros, 2002; Crosta, et al., 2005). $\phi_{a}$ is defined as $\tan \phi_{a}=H / L$, where $H$ is the vertical landslide height of and $L$ is the horizontal landslide length measured from the crest to the toe of the landslide (Fig. 16). This value of $\tan \phi_{a}$ is also called apparent friction, and $\phi_{a}$ apparent friction angle. Low apparent friction angles indicate high mobility. According to Sassa (1996), this apparent friction angle can also be obtained from undrained ring shear test results as the mobilized friction angle at steady state $\phi_{m}=\arctan \left(\tau_{s} / \sigma_{\mathrm{i}}\right)$, where $\tau_{\mathrm{s}}$ is shear strength at steady state and $\sigma_{\mathrm{i}}$ is initial consolidation normal stress. 
Based on the concept of the mobilized friction angle, the possible effect of entrained air on the landslide movement was examined by conducting a series of undrained fast shear tests on air-dried loess samples. The samples were normally consolidated under initial effective normal stresses $\left(\sigma_{\mathrm{i}}\right)$ of 50 and $100 \mathrm{kPa}$. In these tests, the observed pore-air pressures were within a narrow range (20-27 kPa), but the mobilized friction angles were different (Fig. 17). The test under $\sigma_{\mathrm{i}}=100 \mathrm{kPa}$ indicated a mobilized friction angle of 30 degrees during the shear process, whereas the test under $\sigma_{\mathrm{i}}=50 \mathrm{kPa}$ showed a significantly lower value of $\phi_{m}$ of about 13 degrees.

For flow liquefaction cases, it has been found that water-saturated specimens initially consolidated at the same void ratio but at different confining stresses display equivalent steady-state shear resistance (Sladen et al 1985; Ishihara 1993; Kramer 1996; Yang 2002; among others). Hence, the mobilized friction angle will decrease with increasing initial normal stress. However, the results shown in Fig. 17 indicate that, for the air-saturated specimens, the mobilized friction angle increased with increased initial normal stress. This may result from the following facts: (1) air is more compressible than water and, consequently, more compressible space is needed for air-saturated samples to ensure the generation of the same magnitude of pore pressure as for water-saturated samples; and (2) the limited compressible space does not allow the generation of higher pore-air pressure and consequent significant reduction in shear resistance.

From Fig. 17, we can conclude that increased pore-air pressure would have less effect on the mobility of deep-seated landslides because the reduction of effective normal stress from elevated pore-air pressure is negligible when the normal stress is large (i.e., the landslide thickness is great). Moreover, it is worth nothing that the test shown in Fig. 17b was performed under an idealized undrained condition. In the field condition, high permeability of soil with large pore spaces and abundant cracks may enable the quick dissipation of generated air pressure. Hence, any shear-induced generation of air pressure in the field would be smaller than in the laboratory to the extent that its contribution to the high mobility of shallow landslides may be ignored.

From Fig. 2, it is apparent that the landslide materials that underwent long-runout movement mainly came from the left block where a valley existed, while the main body of the displaced material on the right block remained in the source area after moving about $230 \mathrm{~m}$. Although the groundwater condition at the time of landsliding is not available, it is reasonable to infer that the soil layers near or above the sliding surface of the left block may have been fully or highly saturated, while those of the right block may have been partially saturated. Zhang and Wang (2007) examined the effect of the saturation degree on the steady-state strength of loess and found that the apparent friction angles of unsaturated loess were $31^{\circ}$ and $26.6^{\circ}$ at saturation degrees of $5.4 \%$ and $32.6 \%$, respectively. These values are much greater than the saturated friction angle we obtained from our test results (about $2.9^{\circ}$, Fig.11). Therefore, it is reasonable to infer that liquefaction of the fully or highly saturated loess layer was the main reason for the high mobility. Due to the introduction of seismic load during the earthquake, high pore-water pressure was generated within the loess near the sliding surface, resulting in initiation of the landslide. Further increase of pore-water pressure with increasing shear displacement after shear failure occurred may have elevated the mobility of displaced landslide materials.

It is also reasonable to infer that a considerable depth of unsaturated loess above the water table existed within the displaced mass. The unsaturated loess could not liquefy under seismic loading, but could be dynamically fragmented due to the rapid downslope movement. Downslope travel of the moving mass could be 
further accelerated if shear failure and subsequent liquefaction occurred. Strong vibration within the sliding mass could also be initiated, resulting in widespread fluidization, due to following reasons (Iverson, 1997; Iverson et al.,1997): (1) the downslope movement of the sliding mass supplies bulk translational energy which converts to grain/aggregate fluctuation energy when grains/aggregates are under shear along irregular surfaces; and (2) the slope-parallel moving velocity can convert into slope-normal fluctuation velocity when soil layers interact with the rough sliding bed. Continued occurrence of this process can mobilize the whole displaced landslide mass into a flow. In this sense, two reasons may be proposed for the differing movement of the two sub-blocks: (1) the moisture content may have differed at the time of the earthquake. The left sub-block in the pre-existing valley may have had higher moisture content, which promoted the occurrence of fragmentation; (2) the runout lengths of the two blocks were different. Greater runout length would promote the occurrence of the above-mentioned processes and enable fluidization of the entire sliding mass.

Although some researchers consider air lubrication as the reason for the rapid movement of landslides where the displaced landslide materials slide on a thin layer of compressed air after topographic jumps (Kent, 1966; Shreve, 1968), it should be noted that the air pressures needed to support the overburden sliding mass are unrealistically high (Erismann and Abele, 2001) and the agitated sliding mass is relatively permeable so that air pressure is likely to dissipate quickly through the debris. The test results shown in Fig. 17 were obtained under an idealized undrained condition with the introduction of an initial air pressure of $50 \mathrm{kPa}$, which elevated the potential for shear-induced generation of pore-air pressure. However, in the field condition the loess is cut by many vertical joints, which favors the quick dissipation of generated pore-air pressure. Furthermore, fragmentation of the displaced landslide mass would also disenable generation of high air-pressure. Therefore, we consider that the formation of an air cushion would not be possible during the movement of this landslide.

\section{Conclusions}

This paper presents the results of field surveys and experimental investigation of the Dangjiacha landslide triggered by the 1920 Haiyuan, China earthquake. Based on findings of the field surveys and results of undrained triaxial compression tests and ring-shear tests on loess samples taken from the source area, the mechanisms underlying this landslide were evaluated in detail. The following conclusions can be drawn.

(1) Dangjiacha landslide was triggered by the flow liquefaction of loess soil, characterized by high mobility and a large runout distance but along a very gently sloped travel path.

(2) Standing water and shallow groundwater existed in the source area even 80 years after the occurrence of the landslide, providing evidence for the high probability of water saturation of the loess layer near the sliding surface and of the occurrence of liquefaction within this soil layer after the shear failure occurred.

(3) Laboratory tests on the loess samples from the landslide source area showed that they were liquefiable. The water-saturated loess could be liquefied after the slope instability was triggered by the strong earthquake. The big difference between the driving shear stress and the lowered shear resistance of the sliding surface enabled the displaced landslide mass to accelerate, resulting in rapid movement. The rapid downslope movement enabled more soil layers above the sliding layer to be fluidized, finally bringing the whole displaced landslide mass into flow. 
(4) The fast ring shear tests showed that the loess at its natural moisture content with entrapped air had slightly reduced shear strength due to the increase of pore-air pressure. Although the generated pore-air pressure may play a role in the mobility of shallow landslides under an ideal undrained condition, it is unlikely to cause high mobility of large-scale landslides. The high mobility of Dangjiacha landslide was due mainly to the liquefaction failure of the water-saturated loess layers, not to the involvement of air in the movement.

\section{Acknowledgments}

This study was partially supported by two scientific research grants (No. 18380094 and No.23380084) from the MEXT of Japan. Dr. Fanyu Zhang of Lanzhou University is thanked for his help in the field survey and some laboratory testing. We also would like to thank Prof. Masahiro Chigira (Kyoto University) for his help in the microstructure analysis using SEM. Mr. William H. Schulz in U.S. Geological Survey is thanked for his help in editing the final version of this draft. Valuable review comments by Prof. Hungr (the University of British Columbia) in the former version of this draft are appreciated. Finally, our special thanks go to our three anonymous reviewers and Prof. Juang for their valuable comments that substantially improved this paper.

\section{References}

ASTM D422 - 63, 2007. Standard Test Method for Particle-Size Analysis of Soils. 8p.

Bishop, A.W., Green, G.E., Garge, V.K., Andersen, A., Brown, J.D., 1971. A new ring shear apparatus and its application to the measurement of residual strength. Géotechnique, 21(1), 273-328

Bray, J. D., Sancio, R.B., 2006. Assessment of the liquefaction susceptibility of fine-grained soils. Journal of Geotechnical and Geoenvironmental Engineering, 132 (9): 1165-1177.

Bromhead, E. N., 1979. A simple ring shear apparatus. Ground Engineering, 12(5): 40-44.

Casagrande, A., 1936. Characteristics of cohesionless soils affecting the stability of slopes and earth fills, Journal of the Boston society of civil engineers. Reprinted in Contributions to soil mechanics, 1925 to 1940, Boston Society for Civil Engineers, 257-276.

Castro, G., 1969. Liquefaction of sands. Ph.D. Thesis, Harvard University, Cambridge, Massachusetts.

Castro, G., 1975. Liquefaction and Cyclic Mobility of Saturated Sands. ASCE, Geotechnical Engineering Division, 101: 551-569, 1975.

Castro, G., Poulos, S.J., 1977. Factors Affecting Liquefaction and Cyclic Mobility. ASCE, Geotechnical Engineering Division, 103: 501-516.

Chen, Q., Wang, K., Qi, S., Sun, L., 2003. Soil and water erosion in its relation to slope field productivity in hilly gully areas of the Loess Plateau, Acta Ecologica Sinica, 23(8): 1463-1469.

Close, U., McCormick, E., 1922. Where the Mountains Walked, The National Geographic Magazine, 41(5), 445-464.

Crosta, G.B., Imposimato, S., Roddeman, D., Chiesa, S., Moia, F., 2005. Small fast-moving flow-like landslides in volcanic deposits: The 2001 Las Colinas Landslide (El Salvador). Engineering Geology, 19(3-4): 185-214.

Cruden, D. M, Varnes, D.J., 1996. Landslide types and processes. In Landslides: Investigation and Mitigation 
(A.K. Turner \& R.L. Schuster eds): 36-75.

Derbyshire, E., 1991. Landslides in the Gansu Loess of China, Loess-Geomorphological Hazards and Processes, Catena Supplement, 20:119-145.

Derbyshire, E., 2001. Geological hazards in loess terrain, with particular reference to the loess regions of China. Earth-Science Reviews 54: 231-260

Derbyshire, E., Meng, X.M., Dijkstra, T.A., 2000. Landslides in the thick loess terrain of North-West China. John Wiley \& Sons, LTD, Ltd, Chichester.

Dijkstra, T. A., Rogers, C.D.F., Smalley, I.J., Derbyshire, E., Li, Y.J., Meng, X.M., 1994. The loess of north-central China: Geotechnical properties and their relation to slope stability. Engineering Geology, 36: $153-171$.

Erismann, T.H., Abele, G., 2001. Dynamics of Rockslides and Rockfalls. Springer, Heidelberg. 316 pp.

Gibo, S., 1994. Ring shear apparatus for measuring residual strengths and its measurement accuracy. Journal of Japan Landslide Society, 31(3): 24-30.

Habib, P., 1975.Production of gaseous pore pressure during rock slides. Rock Mechanics, 7:193-197.

Howard, K.E., 1973. Valanche mode of motion: implications from lunar examples. Science, 180:1052-1055.

Hsü, K.J., 1975. Catastrophic debris streams (Sturzstroms) generated by rockfalls. Geological Society of America Bulletin, 86: 129-140.

Ishihara, K., 1993. Liquefaction and flow failure during earthquakes. Géotechnique, 43(3), 351-415.

Ishihara, K., Okusa, S., Oyagi, N., Ischuk, A., 1990. Liquefaction-induced Flow Slide in the Collapsible Loess Deposit in Soviet Tajik. Soils and Foundation, 30: 73-89.

Iverson, R.M., 1997. The physics of debris flows. Reviews of Geophysics 35, 245-296.

Iverson, R.M., Reid, M.E., LaHusen, R.G., 1997. Debris-flow mobilization from landslides. Annual Review of Earth and Planetary Sciences 25, 85-138.

Keefer, D. K., 1984. Landslides Caused by Earthquakes. Geological Society of America Bulletin, 95:406-421.

Kent, P. E., 1966. The transport mechanism in catastrophic rock falls. Journal of Geology, 74: 79-83.

Kramer, K.L., 1996. Geotechnical earthquake engineering. Englewood Cliffs, NJ: Prentice Hall.

Liao, C.J., Lee, D.H., Wu, J.H., Lai, C.Z., 2011. A new ring-shear device for testing rocks under high normal stress and dynamic conditions. Engineering Geology, 122(1-2): 93-105.

Legros, F., 2002. The mobility of long-runout landslides. Engineering Geology, 63: 601-611.

Lucchitta, B.K., 1979. Landslides in Valles Marineris, Mars. Journal of Geophysical Research, 84: 8097-8113.

Miao H., Wang, G., Yin, K., Kamai, T., Li, Y., 2014. Mechanism of the slow-moving landslides in Jurassic red-strata in the Three Gorges Reservoir, China. Engineering Geology, 171: 59-69

Okada, Y., Sassa,K., Fukuoka, H., 2004. Excess pore pressure and grain crushing of sands by means of undrained and naturally drained ring-shear tests. Engineering Geology, 75 (3-4), 325-343.

Pautre, A., Sabarly, F., Schneider, B., 1974. L'effet d'échelle dans les écroulements de falaise. In Advances in Rock Mechanics: Proceedings of the $3^{\text {rd }}$ Congress of the International Society for Rock Mechanics, vol. II-B, pp. 859-864, Denver, Colo., 1974

Plafker, G., Ericksen, G.E., 1978. Nevados Huascarán avalanches, Peru. In: B. Voight, Editor, Rockslides and 
Avalanches. 1. Natural Phenomena, Elsevier, Amsterdam, p.277-314.

Poulos, S. J., 1981. The Steady State of Deformation. Geotechnical Engineering Division, ASCE, 107(5): 553-561.

Sassa, K., 1985. The mechanism of debris flows. In Proceedings of the 11th International Conference on Soil Mechanics and Foundation Engineering, San Francisco, Calif. Vol. 3, pp. 1173-1176.

Sassa, K., 1996. Prediction of earthquake induced landslides, Special Lecture of 7th International Symposium on Landslides, "Landslides", Rotterdam: Balkema, 1:115-132.

Sassa, K., Fukuoka, H., Wang, G., Ishikawa, N., 2004. Undrained dynamic-loading ring-shear apparatus and its application to landslide dynamics. Landslides, 1(1): 9-17.

Sassa, K., Wang, G., Fukuoka, H., 2003. Performing undrained shear tests on saturated sands in a new intelligent type of ring shear apparatus. Geotechnical Testing Journal, ASTM, 26(3): 257-265.

Scheidegger, A.E., 1973. On the Prediction of the Reach and Velocity of Catastrophic Landslides. Rock Mechanics, 5: 231-236.

Seed, H.B., 1966. Landslides During Earthquakes due to Soil Liquefaction. Journal of Soil Mechanics Foundations Division, ASCE, 94(5): 1055-1122.

Seed, H.B., Idriss, I.M., 1982. Ground motions and soil liquefaction during earthquakes. EERI Monograph, Berkeley, Calif.

Shreve, R.L., 1968. The Blackhawk Landslide. Geological Society of America, Special Paper, 108:1-49.

Skempton, A.W., 1954. The pore-pressure coefficient A and B. Géotechnique, 4:143-147.

Sladen, J.A., D'Hollander, R.D., Krahn, J., 1985. The liquefaction of sands, a collapse surface approach. Canadian Geotechnical Journal, 22: 564-578.

Ter-Stepanian, G., 1998. Suspension force induced landslides, Proceedings of 8th International Congress International Association for Engineering Geology and the Environment, Vancouver, Canada. Balkema, Rotterdam, 3:1905-1912.

Tika, Th.E., Hutchinson, J.N., 1999. Ring shear tests on soil from the Vaiont landslide slip surface. Géotechnique, 49(1): 59-74.

Vaid, Y.P., Chern, J.C., 1983. Effect of static shear on resistance of liquefaction. Soils and Foundations, Vol. 23, No. 1, pp. 47-60, 1983.

Vaid, Y.P., Chern, J.C., 1985. Cyclic and monotonic undrained response of saturated sands. In Advances in the Art of Testing Soils under Cyclic Conditions (V. Khosla edited), ASCE, New York, pp.120-147.

Varnes, D.J., 1978. Slope Movement Types and Processes, "Landslides - Analysis and Control", Special Report, No. 176, Transportation Research Board, National Academy of Sciences, USA, 11-33.

Wang, F.W., Sassa, K., Wang, G., 2002. Mechanism of a long-runout landslide triggered by the August 1998 heavy rainfall in Fukushima Prefecture, Japan. Engineering Geology 63, 169-185.

Wang, G., Sassa, K., 2002. Post-failure mobility of saturated sands in undrained load-controlled ring shear tests. Canadian Geotechnical Journal 39, 821-837.

Wang, G., Sassa, K., Fukuoka, H., 2003. Downslope volume enlargement of a debris slide-debris flow in the 1999 Hiroshima, Japan, rainstorm. Engineering Geology, 69: 309-330 
Wang, G., Sassa, K., Fukuoka, H., Tada, T., 2007. Experimental Study on the Shearing Behavior of Saturated Silty Soils Based on Ring Shear Tests. Journal of Geotechnical and Geoenvironmental Engineering, ASCE 133(3): 319-333.

Wang, L.M., Wang, Y.Q., Wang, J., Li, L., Yuan Z.X., 2004. The liquefaction potential of loess in China and its prevention. Proceedings of 13th World conference on earthquake engineering, Vancouver, B.C., Canada, paper No.3462, 13p

Wang, W., 1979. Some findings in soil liquefaction. Water Conservancy and Hydroelectric Power Scientific Research Institute, Beijing, China. 1979.

Wen, B.P., Yan, Y.J., 2014. Influence of structure on shear characteristics of the unsaturated loess in Lanzhou, China. Engineering Geology, 168:46-58.

Yang, J., 2002. Non-uniqueness of flow liquefaction line for loose sand. Géotechnique, 52(10): 757-760.

Yoshimi, Y., 1991. Liquefaction of Sands. Gihoudo Press, Co. Ltd. Tokyo, 182pp (in Japanese).

Zhang, D., Sassa, K., 1996. Study of the Mechanism of Loess Landslides Induced by Earthquakes. Journal of the Japan Society of Erosion Control Engineering, 49: 4-13 (in Japanese).

Zhang, D., Takeuchi, A., Sassa, K., 1995. The Motion Characteristics of Loess Landslides Induced by the Haiyuan Earthquake in Ningxia Province, China. Journal of the Japan Landslide Society, 32(1): 12-17 (in Japanese).

Zhang, D., Wang, G., 2007. Study of the 1920 Haiyuan earthquake-induced landslides in loess (China). Engineering Geology, 94: 76-88.

Zhang, F.Y., Wang, G., Kamai, T., Chen, W.W., Zhang, D.X., Yang, J., 2013. Undrained shear behavior of loess saturated with different concentrations of sodium chloride solution. Engineering Geology, 155: 69-79.

Zhang, Z., Wang, L., 1995. Geological disasters in loess areas during the 1920 Haiyuan Earthquake, China. GeoJournal, 36: 269-274.

Zhu, H., 1989a. The Geological Characteristics of Landslides Induced by Earthquakes in China, Proceedings of the Japan-China Symposium on Landslides and Debris Flows, Niigata, Tokyo, 161-168. Workshop on Loess Geomorphological Processes and Hazards, 64-71. 


\section{Figure Caption:}

538 Fig. 1. Location of loess landslides area on the map of China

539 Fig. 2. Dangjiacha landslide in Xiji, Ningxia, triggered by the 1920 Haiyuan Earthquake (photo was taken in

540 1966). W1, W2: locations of Well 1 and Well 2; S1, S2: sampling locations of undisturbed and disturbed loess, 541 respectively.

542 Fig. 3. Topographic map of the Dangjiacha landslide area.

543 Fig. 4. Cross section along Line I-I' (a), longitude section along Line II-II' (b) and Line D-E-F-G (c) in Fig. 2, 544 respectively.

545 Fig. 5. Wells located in the right (a) and left (b) sliding blocks and the investigation pit (c) near the well W1

546 Fig. 6. Void ratios of loess soils at different elevations along line D-E in Fig. 2. S1: Sampling location of 547 undisturbed loess.

548 Fig. 7. Grain size distribution of loess from the source area of the right sliding block.

549 Fig. 8. Microstructures of undisturbed sample. (a) $\times 300$, and (b) $\times 500$.

550 Fig. 9. Microstructures of disturbed sample. (a) $\times 300$, and (b) $\times 500$.

551 Fig. 10. Results from undrained triaxial compression tests performed on saturated, undisturbed loess samples (e=0.79). (a) Pore-water pressure against axial strain; (b) Effective stress path. FLL: Flow Liquefaction Line.

Fig. 11. Undrained response of water-saturated loess sample to monotonic shearing. (a) Normal stress, shear resistance and pore-water pressure versus shear displacement; (b) Effective stress path $(\mathrm{e}=1.06)$

Fig. 12. Undrained response of water-saturated loess sample to cyclic loading in the ring shear test. (a) Time series of normal stress, shear resistance, pore-water pressure and shear displacement; (b) Effective stress path $(\mathrm{e}=0.99)$

558 Fig. 13. Undrained response to fast shearing of loess at its natural water content with entrapped air. (a) Time series data; (b) Mobilized friction angle and reduction in sample height versus shear displacement; (c) Specimen states before shearing (left) and after 6 seconds of shearing (right) $(e=1.42)$.

Fig. 14. Undrained triaxial compression tests on remolded sample ( $\mathrm{e}=0.79)$. (a) Pore-water pressure against axial strain; (b) Effective stress path. FLL: Flow Liquefaction Line.

563 Fig. 15. Shear resistance at steady state versus void ratio for water-saturated loess samples

564 Fig. 16. Definition of the travel angle $\left(\phi_{a}\right)$ for a landslide

565 Fig. 17. Results of tests on air-dried loess samples that were consolidated under the initial stress of (a) $100 \mathrm{kPa}$

$566 \quad(\mathrm{e}=1.42)$, and (b) $50 \mathrm{kPa}(\mathrm{e}=1.43)$. 


\section{Figures:}

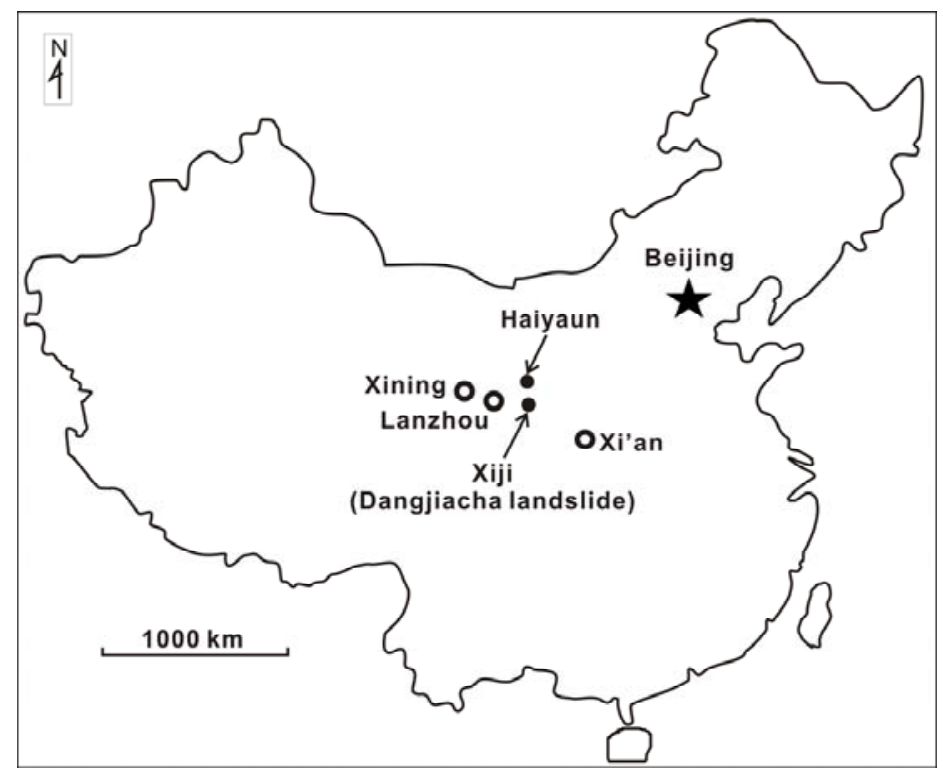

Fig. 1. Location of loess landslides area on the map of China

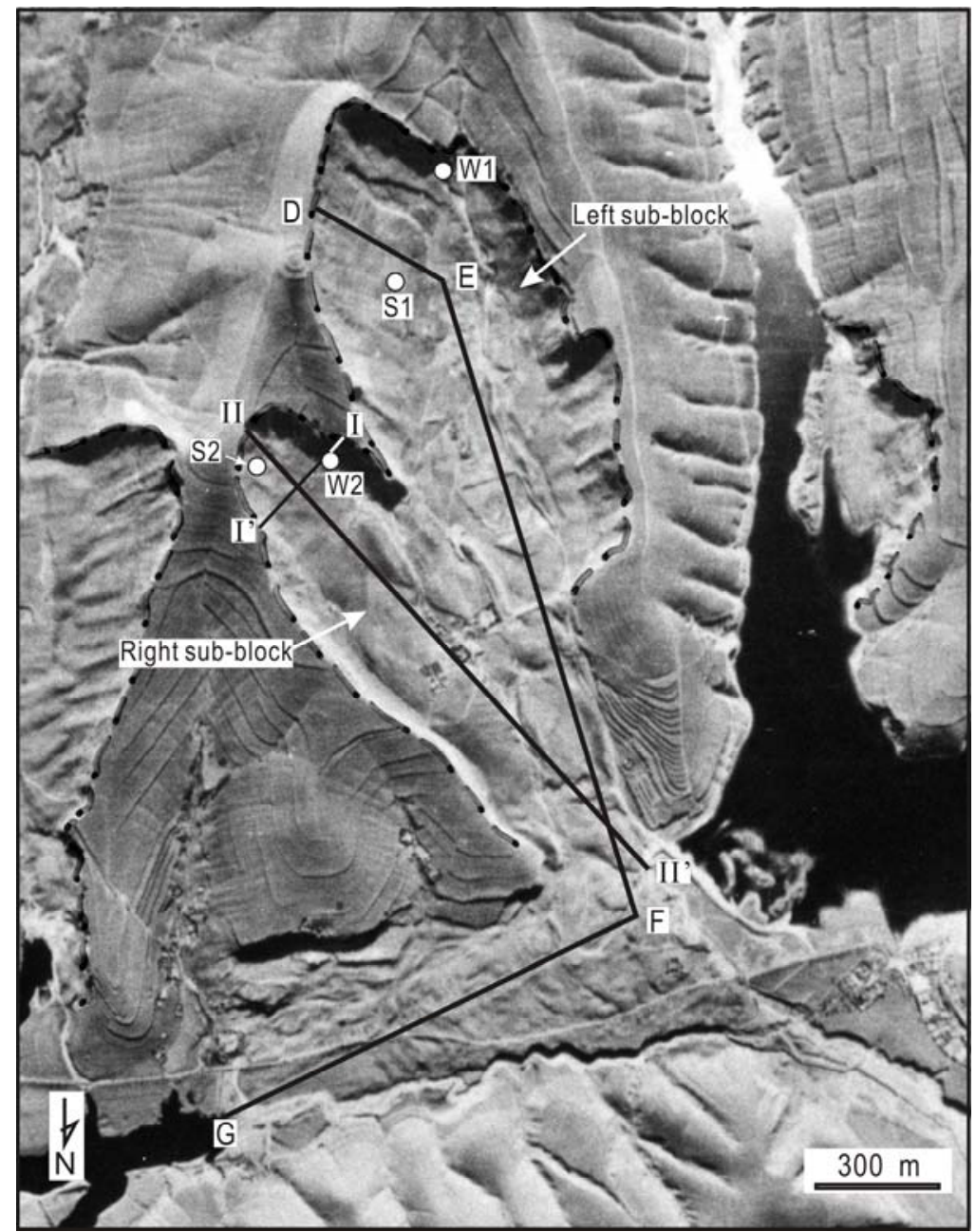

Fig. 2. Dangjiacha landslide in Xiji, Ningxia, triggered by the 1920 Haiyuan Earthquake (photo was taken in 1966). W1, W2: locations of Well 1 and Well 2; S1, S2: sampling locations of undisturbed and disturbed loess, respectively. 


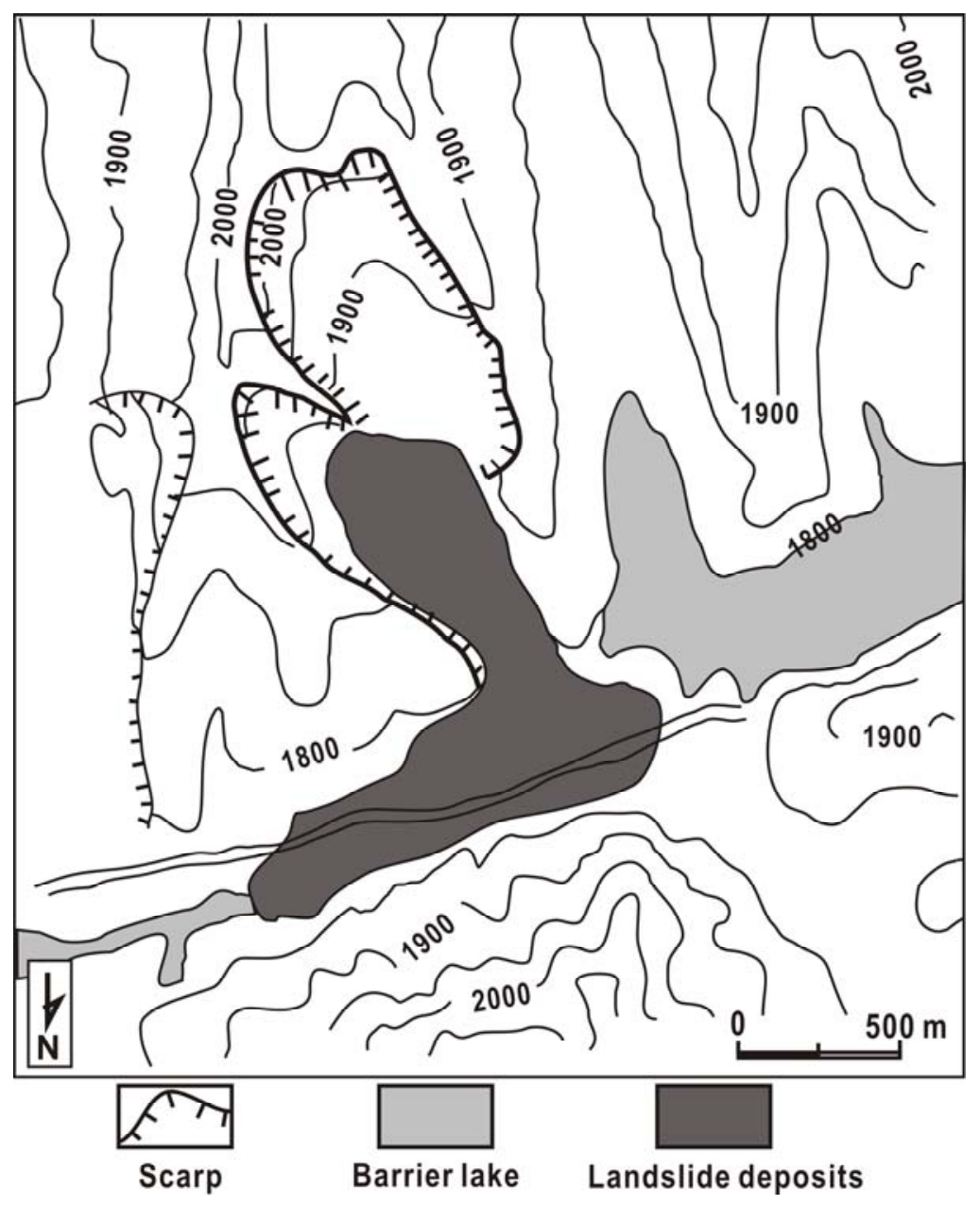

Fig. 3. Topographic map of the Dangjiacha landslide area. 

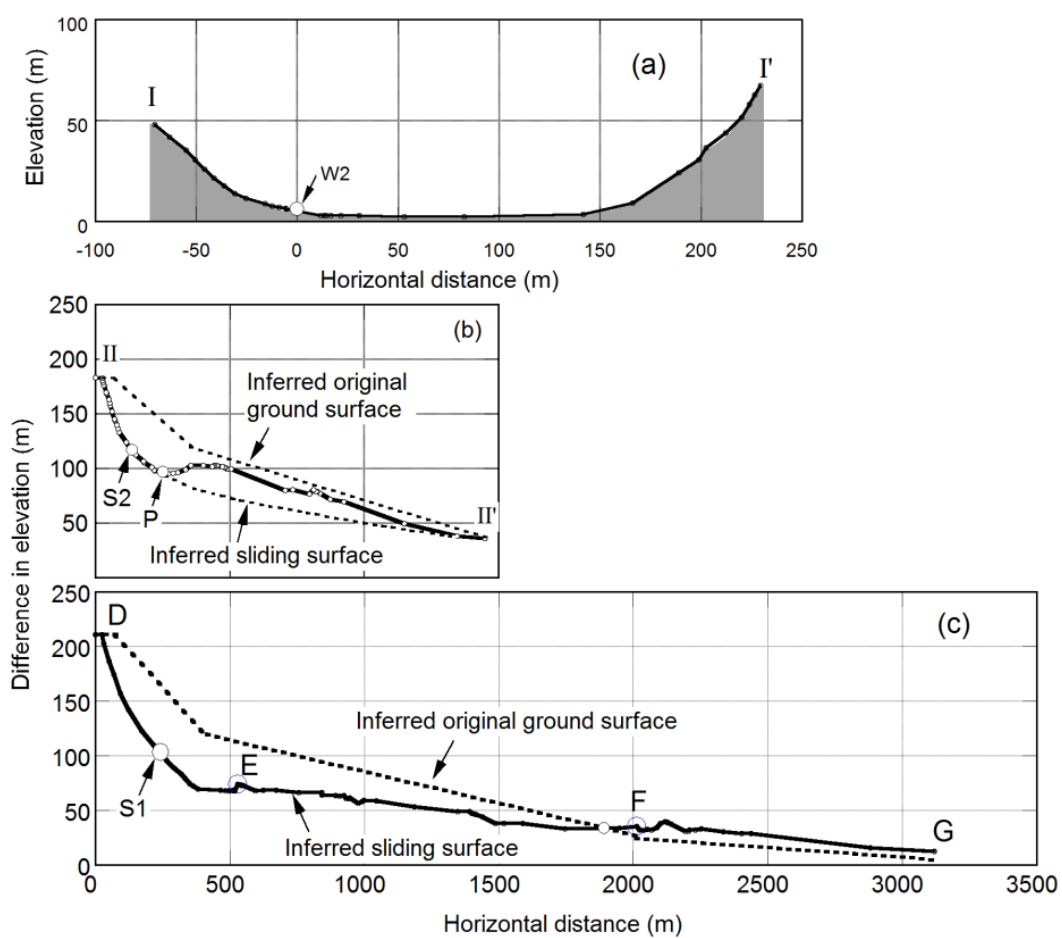

Fig. 4. Cross section along Line I-I’ (a), longitude section along Line II-II’ (b) and Line D-E-F-G (c) in Fig. 2, respectively.
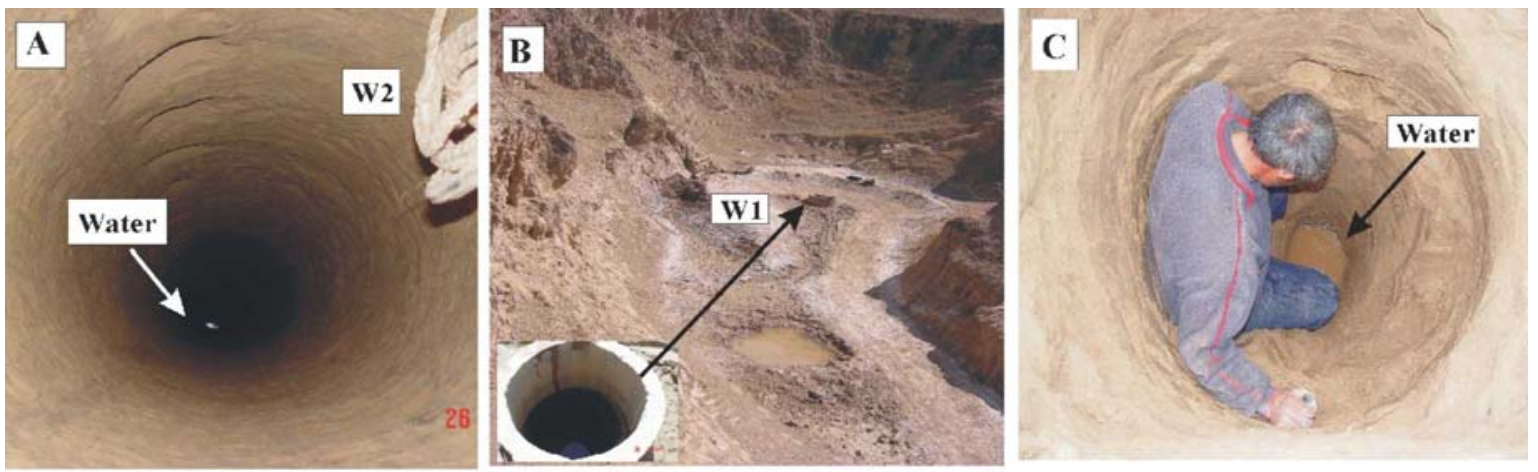

Fig. 5. Wells located in the right (a) and left (b) sliding blocks and the investigation pit (c) near the well W1 


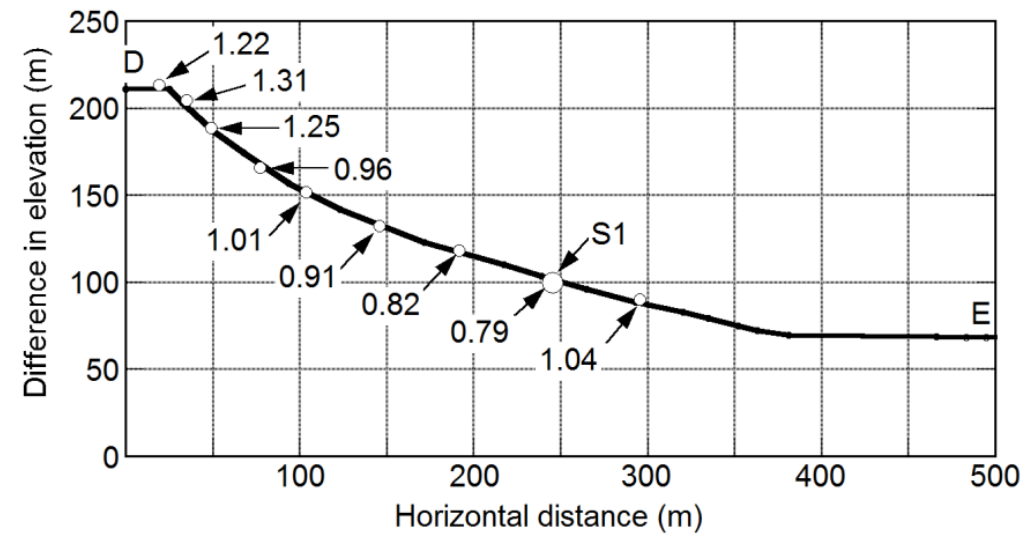

Fig. 6. Void ratios of loess soils at different elevations along Line D-E in Fig.2. S1: Sampling location of undisturbed loess.

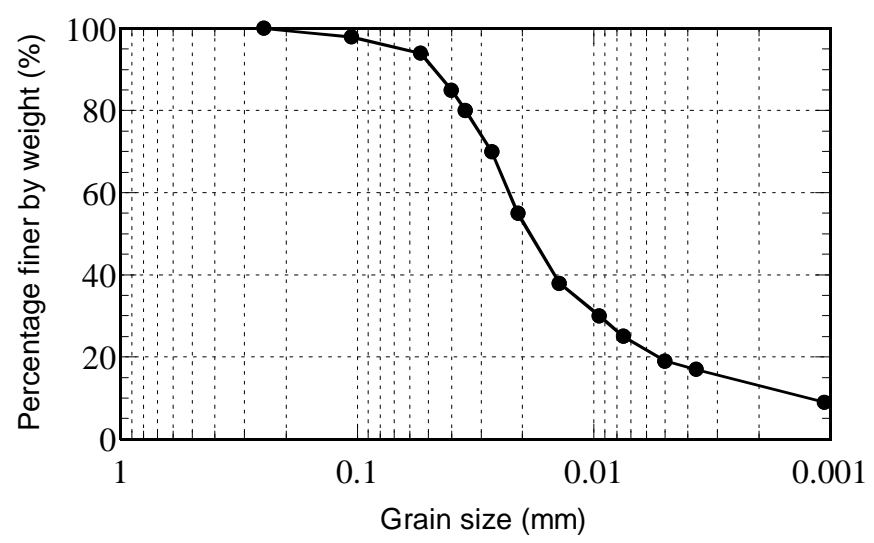

Fig. 7. Grain size distribution of loess sample from the source area of the right sliding block. 

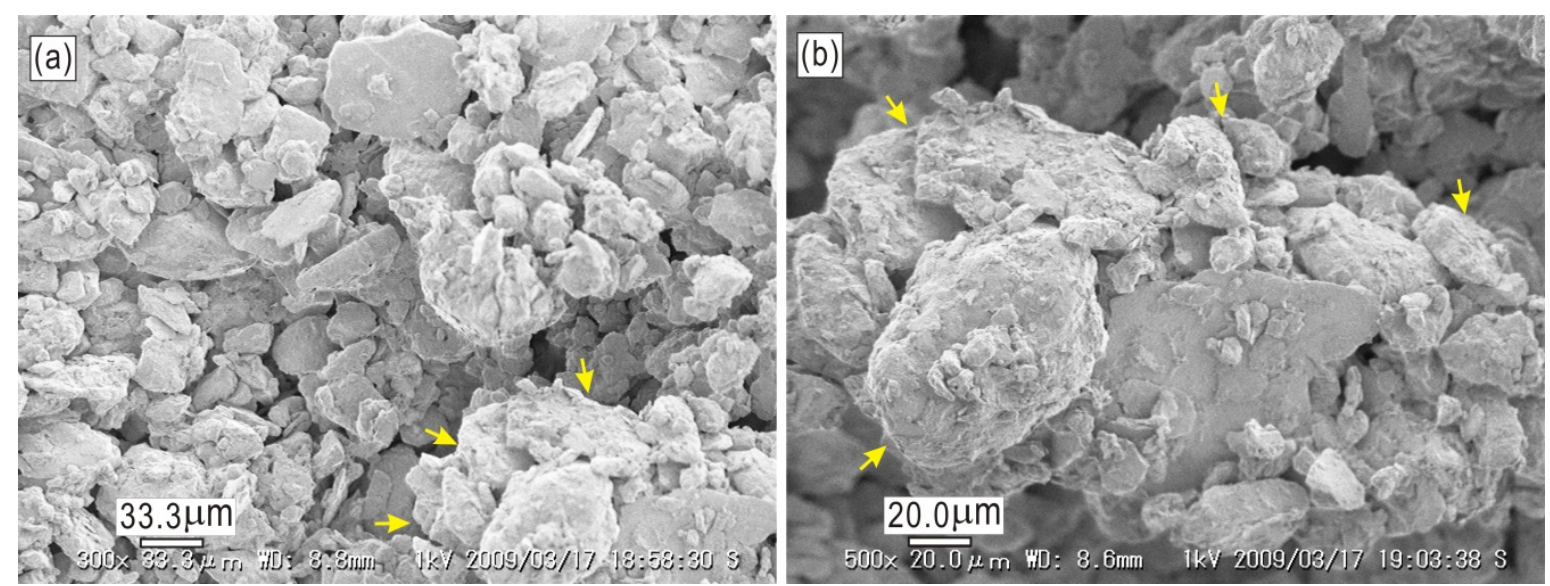

Fig. 8. Microstructures of undisturbed sample. (a) $\times 300$, and (b) $\times 500$.

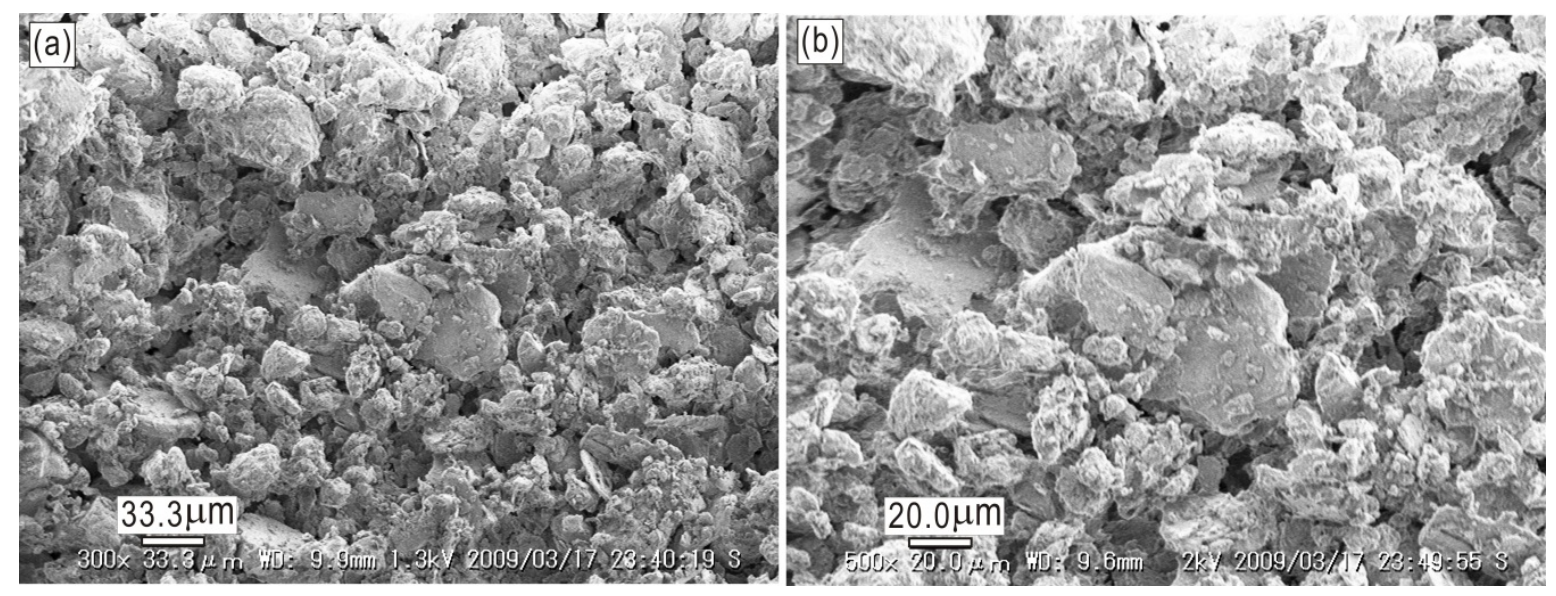

Fig. 9. Microstructures of disturbed sample. (a) $\times 300$, and (b) $\times 500$. 

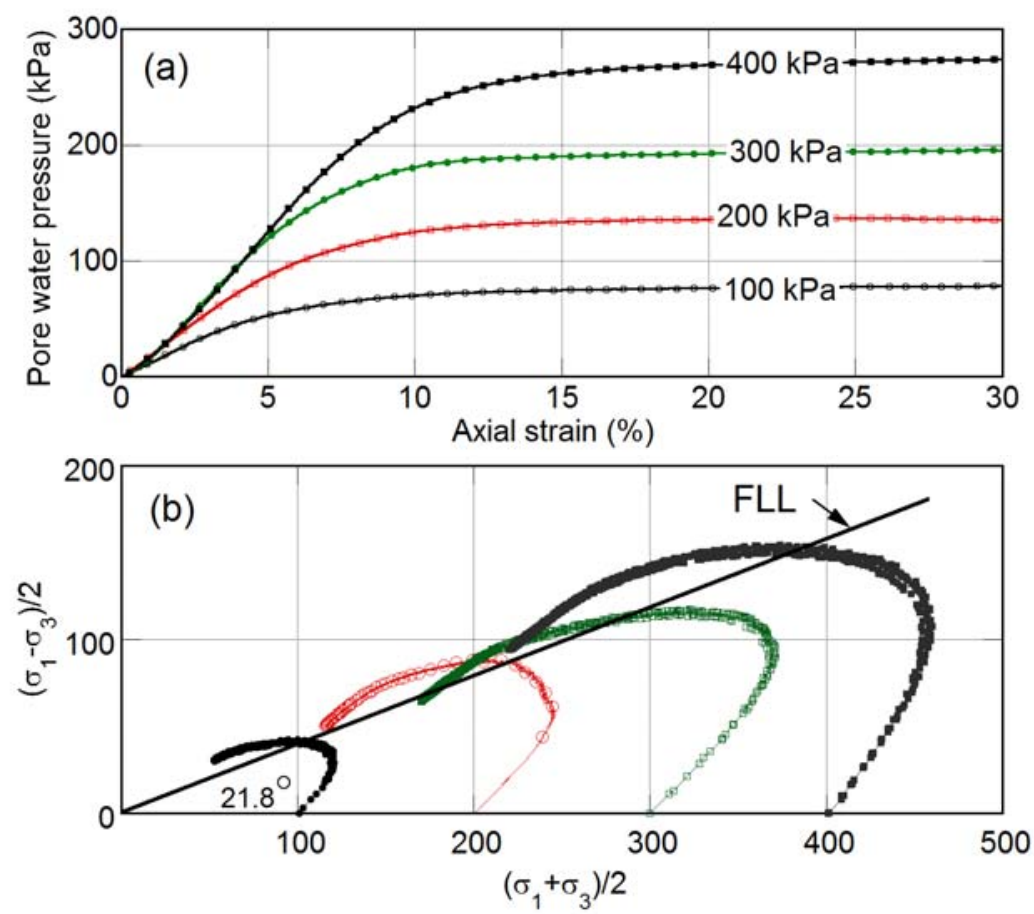

Fig. 10. Undrained triaxial compression test results on saturated undisturbed loess samples ( $\mathrm{e}=0.79$ ). (a)

Pore-water pressure against axial strain; (b) Effective stress path. FLL: Flow Liquefaction Line.
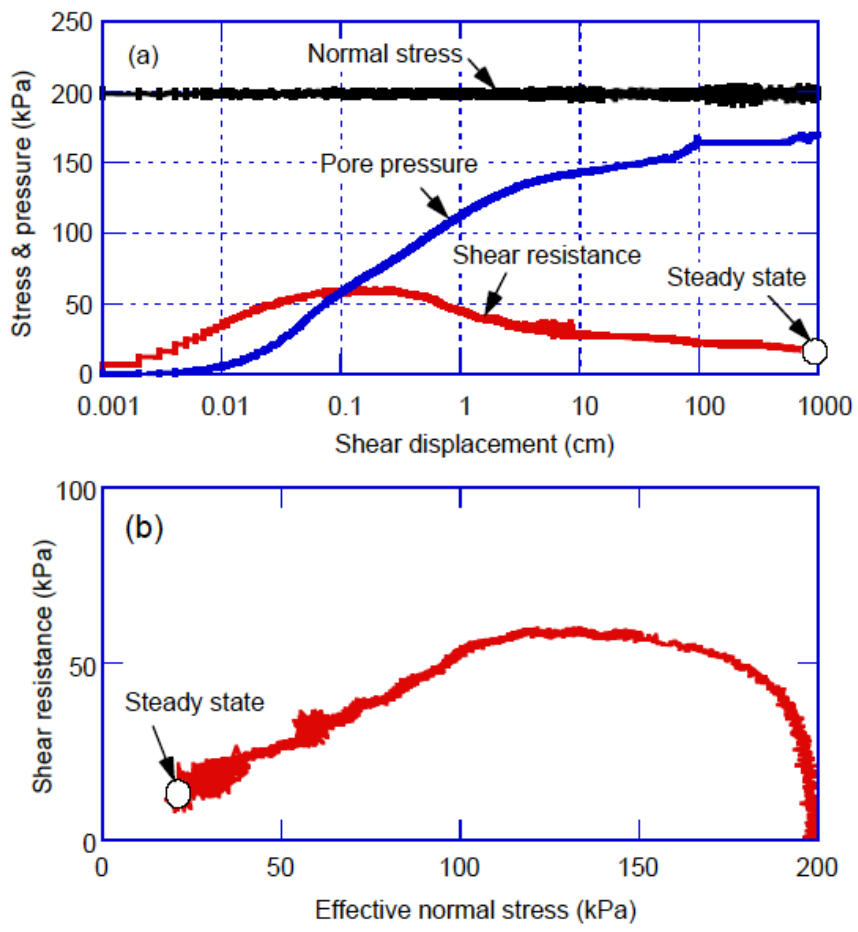

Fig. 11. Undrained response of water-saturated loess sample to monotonic shearing. (a) Normal stress, shear resistance and pore-water pressure versus shear displacement; (b) Effective stress path $(\mathrm{e}=1.06)$ 

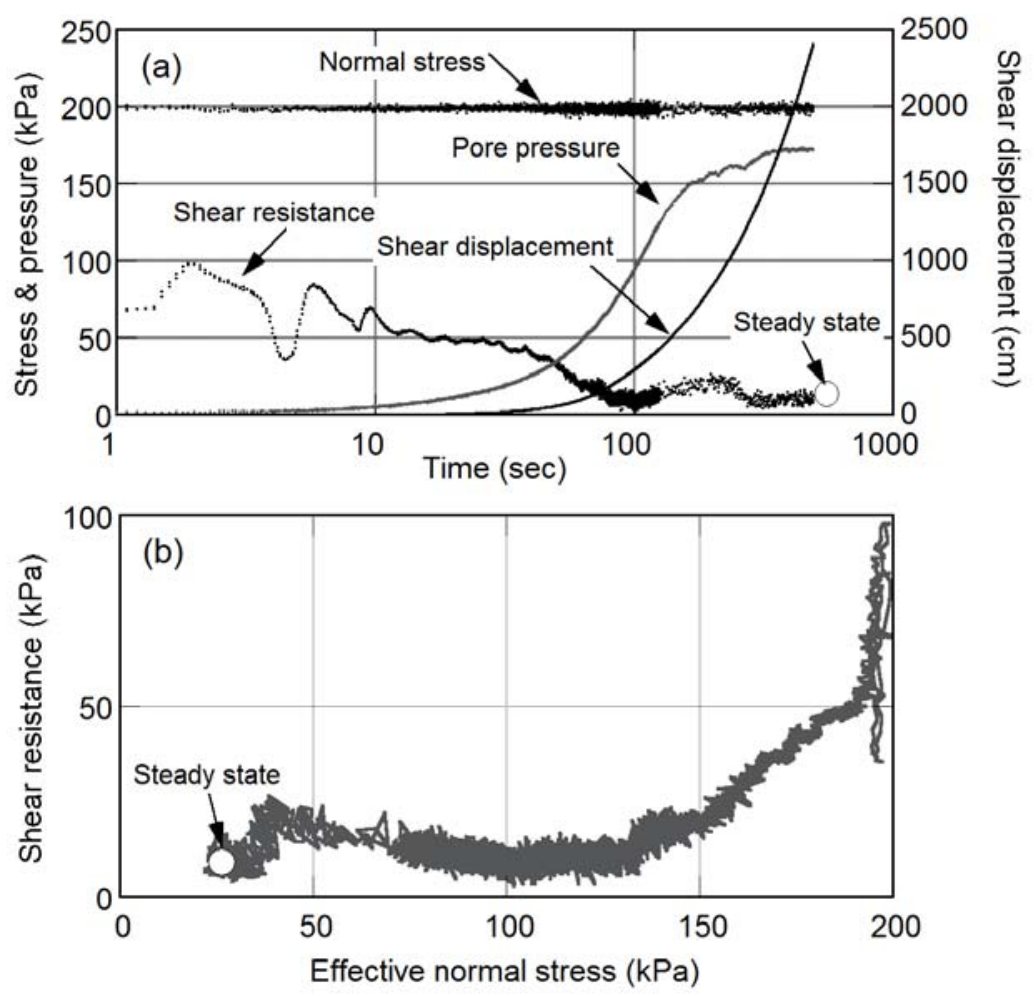

Fig. 12. Undrained response of water-saturated loess sample to cyclic loading in ring shear test. (a) Time series data of normal stress, shear resistance, pore-water pressure and shear displacement; (b) Effective stress path $(\mathrm{e}=0.99)$ 

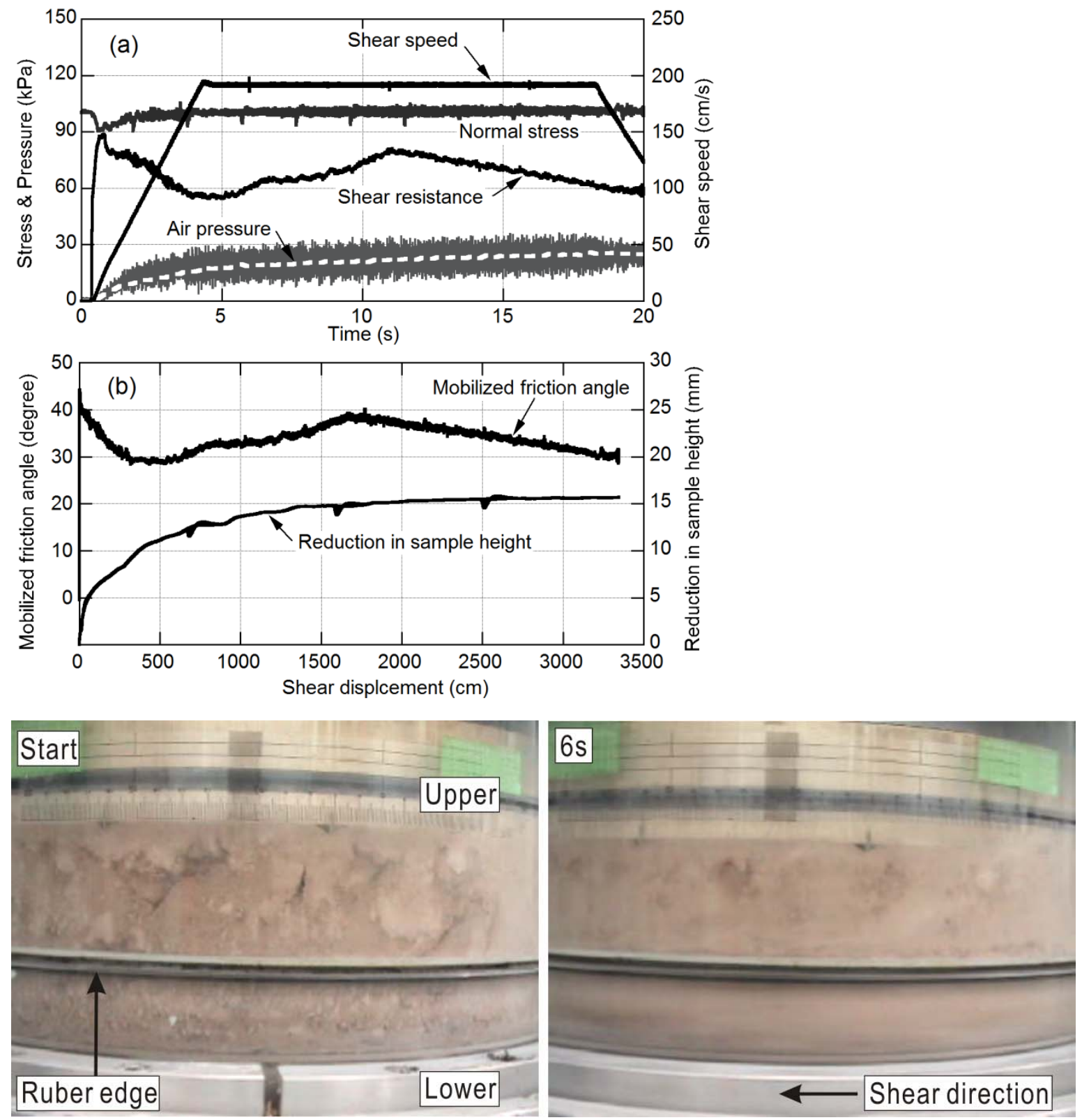

Fig. 13. Undrained response to fast shearing of loess sample in natural water content state with entrapped air.

(a) Time series data; (b) Mobilized friction angle and reduction in sample height versus shear displacement; (c) Specimen states before shearing (left) and after 6 seconds of shearing (right) $(\mathrm{e}=1.42$ ). 

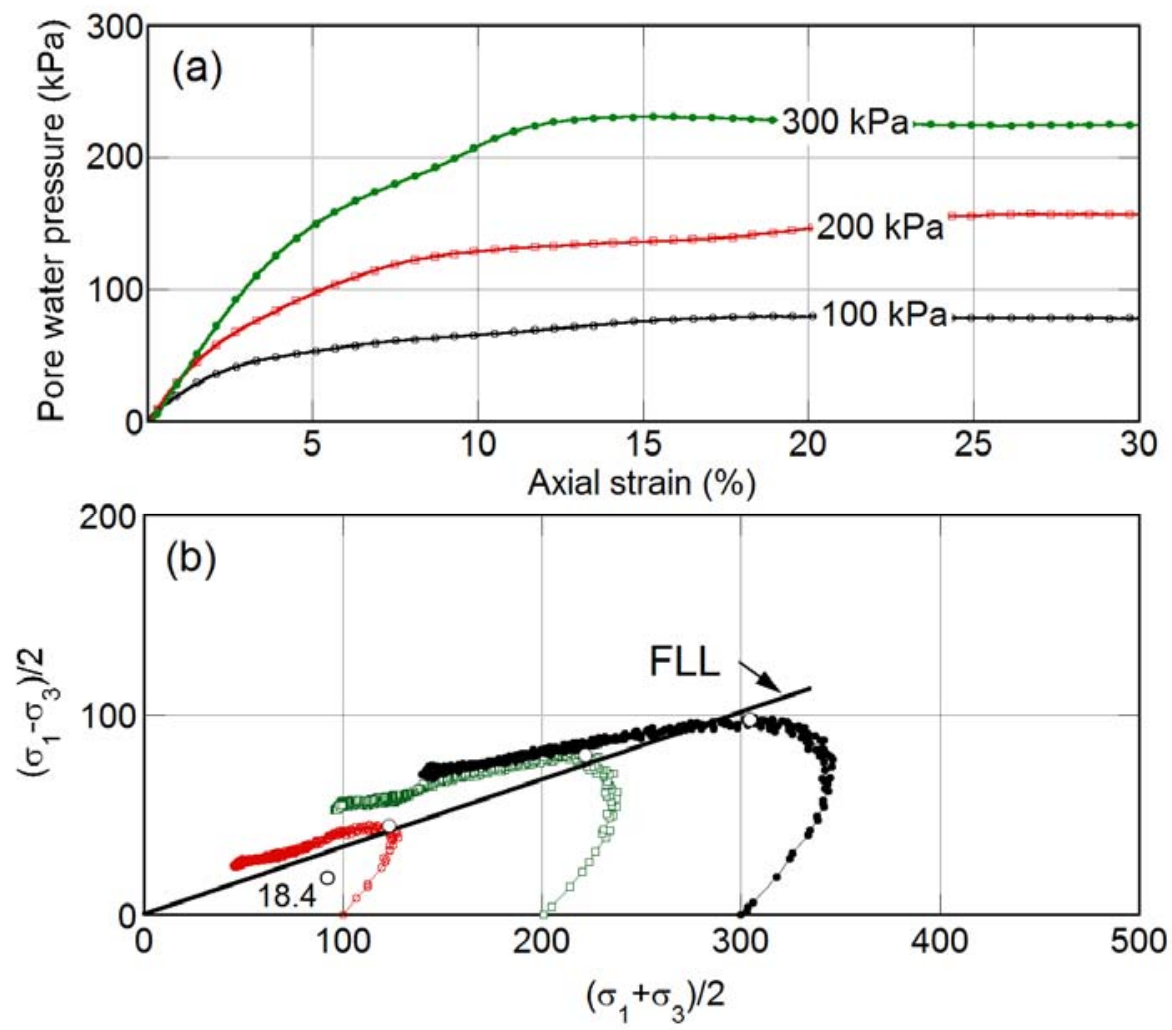

Fig. 14. Undrained triaxial compression tests on remolded sample ( $\mathrm{e}=0.79)$. (a) Pore-water pressure against axial strain; (b) Effective stress path. FLL: Flow Liquefaction Line.

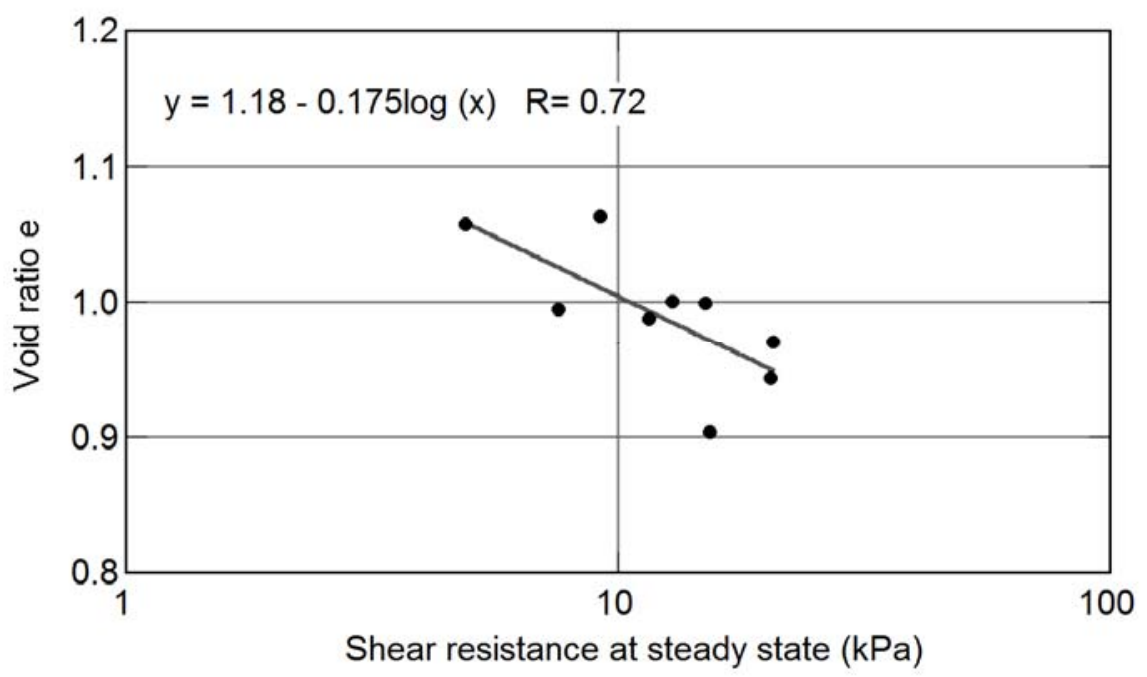

Fig. 15. Shear resistance at steady state versus void ratio for water-saturated loess samples 


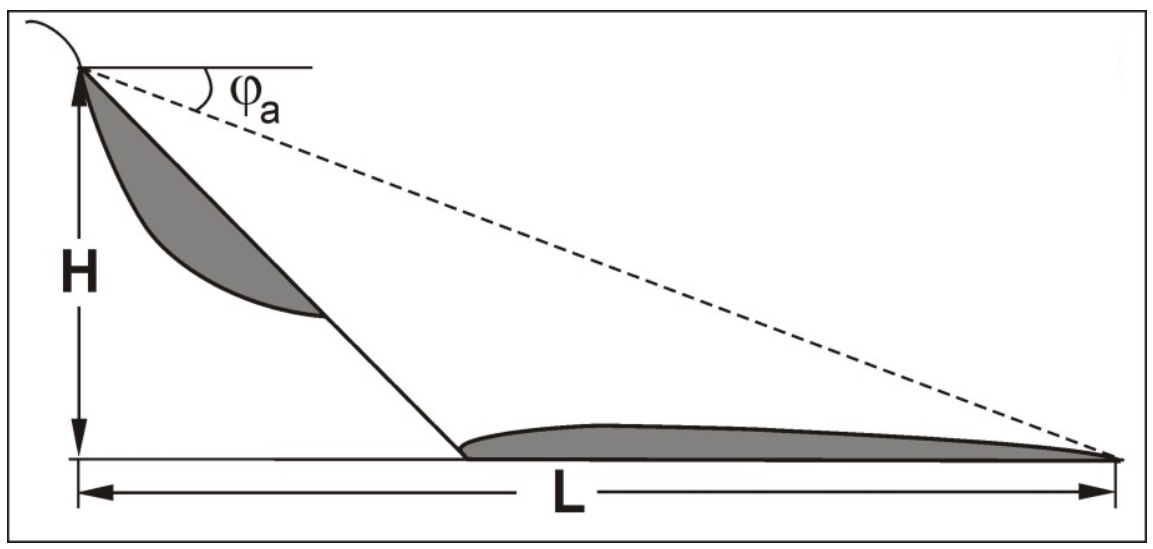

Fig. 16. Definition of the travel angle $\left(\phi_{a}\right)$ for a landslide

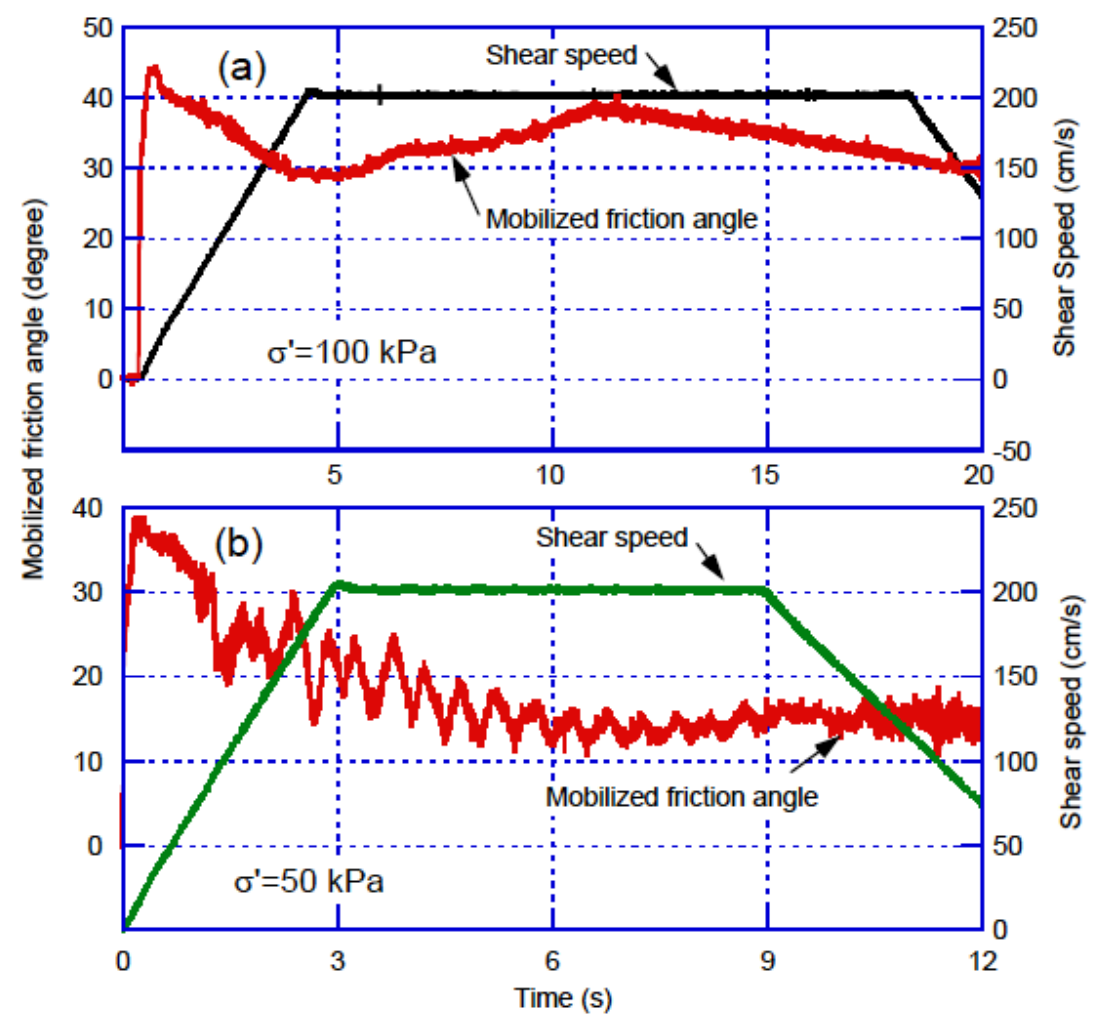

Fig. 17. Results of tests on air-dried loess samples that were consolidated under the initial stress of (a) 100

$\mathrm{kPa}(\mathrm{e}=1.42)$, and (b) $50 \mathrm{kPa}(\mathrm{e}=1.43)$, respectively. 